\title{
KRATKE EKSPRESIONISTIČKE PROZNE VRSTE KAO ZNAK MODERNIZACIJE U SLOVENAČKOJ KNJIŽEVNOSTI
}

U ovom radu pokušali smo da predstavimo značaj kratkih ekspresionističkih proznih vrsta za modernizaciju slovenačke književnosti u periodizacijskom okviru od 1914. do 1935. godine kroz osnovne strukturne i morfološke odlike novele, kratke priče, crtice i pesme u prozi. Temeljna ishodišta i kontroverze nemačkog ekspresionističkog pokreta prema modernizmu i avangardi potvrđuju medijalnu poziciju ovog pokreta i u slovenačkoj književnosti. Ova tvrđenja zahtevaju naučnu verifikaciju unutar što obuhvatnije tekstualne baze različitih poetičko-stilskih predstavnika slovenačke ekspresionističke proze.

Ključne reči: nemački ekspresionistički pokret, modernizam, avangarda, kratke prozne vrste, recepcija, model ekspresionističkog proznog teksta

Značaj kratke proze (pesma u prozi, aforizam, misaona slika, skica, anegdota, feljton, mikropriča, kratka priča, autobiografska zabeleška) i njen izuzetan uticaj na razvoj moderne književnosti u novije vreme je predmet sve brojnijih teorijskih i istorijsko-genoloških, ali i komparativnih istraživanja. Pojedini nemački teoretičari definišu je kao svojevrsno „tekstualno polje“ u književnom sistemu modernizma (Althaus, Bunzel 2007: 7) u kom se odvijaju neutralisanje i relativizacija ne samo žanrovskih odlika proze, već i poezije.

Naučni pristup problemu kratkih proznih vrsta u slovenačkom ekspresionizmu može se definisati kao „metod koncentričnih krugova“, ili kao postupak koji uzima u obzir specifične zahteve za žanrovskom sistematizacijom unutar jednog avangardnog pokreta, obuhvatnije prozne vrste ili autorskog opusa. Zbog toga je naša monografija Morfologija ekspresionističke proze (2003) utemeljena na prožimanju deduktivne i induktivne metode, s ciljem da se najpre istraži opšti fenomen, preko konkretnih modaliteta u pojedinim kratkim proznim žanrovima, do tumačenja određenih tekstova 
najznačajnijih ekspresionističkih predstavnika.

Imajući ovo u vidu, najpre je nužno eksplicirati temeljne odnose između nemačkog ekspresionističkog pokreta prema širim tipološko-estetičkim kategorijama modernizma, odnosno avangarde, kao i zastupljenost ekspresionizma u drugim evropskim i južnoslovenskim književnostima. Od posebnog značaja je i diskusija o fenomenu ekspresionističke proze u brojnim prilozima nemačkih teoretičara, književnih istoričara, kritičara i samih pisaca od 1910. godine do danas. To ujedno otvara pitanje kriterijuma za određivanje modela ekspresionističkog proznog teksta s obzirom na razvojne tendencije i morfologiju pomenutih modernih kratkih proznih vrsta, kao i njihovog odnosa prema srednjim narativnim žanrovima (pripovetka, pripovest) i dugim ( roman).

Zbog neodređenih definicija ekspresionističke proze koje su uglavnom uzimale u obzir samo njene stilske odlike, potreban nam je nov, fleksibilniji model ekspresionističkog proznog teksta u kom će čitalac samostalno identifikovati pojedine kriterijume koji ga definišu. Model je najpre isproban na materijalu nemačke ekspresionističke proze i može da predstavlja paradigmatičan primer sličnim pojavama u drugim evropskim i južnoslovenskim književnostima (Stojanović Pantović 1998: 18-23). Prilikom određenja ovog modela rukovodili smo se sledećim aspektima: Poetološko-konceptualni aspekti, Ekspresionistički toposi, Morfološki i narativni aspekti, Stilsko-jezički aspekti i Semantičke implikacije. Uočavanje odstupanja i razlika koje se javljaju na različitim nivoima ovog hipotetičkog modela u pojedinim nacionalnim literaturama u odnosu na nemačku, takođe spada u domen pluralne poetike ekspresionističke proze.

Prvi aspekt odnosi se na poetička i filozofska ishodišta ekspresionističkog pokreta u kom su ključne tačke egzistencijalna podvojenost subjekta, socijalni kod, kao i pobuna protiv postojećih institucija civilizacije. Posebno je pitanje estetske revalorizacije koja odbacuje ideju o metafizičkim kategorijama lepote i artizma, vodećih u simbolizmu, i ističe kategorije ružnoće, distorzije, šoka i groteske. Ekspresionistički toposi su tematsko-motivske konstante koje se često pojavljuju u međusobnom odnosu opozicije ili dopune. Među njih ubrajamo topose usamljenosti i straha, vizije i ludila, motive rata i apokalipse, pojavnog i suštinskog, zvuka i ritma, dinamike i statike, uma i tela, duhovnosti i seksualnosti, muškarca i žene, vizuelizaciju boja i geometrijske oblike. Rodna perspektiva ekspresionističke proze 
je posebno zanimljiva i podrazumeva svojevrsnu krizu maskuliniteta, kao i naglašenu idealizaciju žene, odnosno mizoginiju (Stojanović Pantović 2010: 955-960).

U slučaju morfoloških i narativnih odlika ekspresionističkog proznog teksta, zapazili smo da se u najvećoj meri preklapaju sa karakteristikima moderne i avangardne proze u celini. To pretežno implikuje antimimetičko konstruisanje teksta, što je svakako u skladu sa poetičkim stavovima ekspresionistickih pisaca (Ajnštajn, Deblin, Kafka) i njihovim negativnim odnosom prema psihološko-kaizalnoj motivaciji i zaokruženoj fabuli. Kod njih pretežno preovlađuje semiotičko-konstruktivni princip oblikovanja proznog teksta zasnovanog na postupku montaže. Ovome su takođe prilagođene figure-maske i osnovni modusi pripovedanja: auktorijalni narator, pripovedanje u prvom licu (koje je možda i najčešće) i personalizacija naracije preko tzv. reflektor figure.

Stilski i jezički aspekti modela podrazumevaju „decentriranje“ logocentričnog proznog diskursa. Obiljem asocijativnih veza jezik deluje svojom diferencijalnom prirodom unutar konvencionalnog označiteljskog sistema i ujedno relativizuje kompleksne relacije znaka i označenog. Zbog toga se ekspresionistički stil ne može svesti samo na njegove retoričke karakteristike, već takođe uključuje istorijsku, kulturnu i semiotičku kategoriju teksta, kao što je pisao Rolan Bart Bart u svojoj studiji Stil i njegova slika (1974). Stoga je moguće govoriti o dve glavne tendencije ekspresionističkog stilskog postupka, kako je to analizovao Valter Zokel (Sokel 1970). Reč je o postupku simultanizma, koji je nasleđen od naturalista, i parabolično-alegorijski stil, po ugledu na romantičare. Oba mogu biti prisutna kod istog pisca. Istovremeno su važne i funkcije unutrašnjeg monologa, esejizacija i metatekstualna ravan pripovedanja, koju pomenuti savremeni teoretičari smatraju ključnom karakteristikom ekspresionističkog stila.

Temeljna semantička ishodišta ekspresionističke proze ciljaju na dva osnovna kruga pitanja. Prvi je usredsređen na spoznajno-kritičku svest pisca prema realnosti i jeziku, dok drugi krug problema obuhvata promišljanje egzistencijalnih kategorija kao što su život, ljubav, seksualnost, moral, žena, odnos polova, Bog i smrt, i konačno odnos prema sebi, prema sopstvenoj podvojenosti.

Skicirani model ekspresionističkog proznog teksta predstavlja uvod $\mathrm{u}$ razmatranje ovog problema u slovenačkoj književnosti, kao i uloge poetske proze u okviru poetike ovog pokreta. Mnogi književni istoričari i teoretičari od dvadesetih 
godina prošloga veka do danas nisu imali i još uvek nemaju jedinstven pogled na prisustvo ekspresionizma u slovenačkoj književnosti, smatrajući ga pre fazom ili tokom unutar modernističke književnosti, nego i specifičnim književnoestetskim fenomenom. Tako je u svojoj uticajnoj studiji Ekspresionizem (1986) Lado Kralj izneo stav da je slovenački književni ekspresionizam pokret, tok ili struja koja je uslovljena radikalizacijom strukture slovenačke moderne, a ne bitno nova književna pojava. To znači da ekspresionizam nema unutarnju koherenciju koja odlikuje neke druge stilske formacije ili pravce, poput realizma ili naturalizma (Stojanović Pantović 2003: 16-23).

Kada je u pitanju tekstualna baza slovenačke ekspresionističke proze, zapaža se još veći stepen nesigurnosti i uzdržanosti. Postavlja se načelno pitanje da li opisani model ekspresionističkog proznog teksta uopšte postoji i koji su sve to kriterijumi za njegovo određenje. Lado Kralj smatra da se ekspresionizam realizovao u slovenačkoj poeziji, delimično u drami, a gotovo nikako u prozi. Razumljivo je da ovi zaključci zahtevaju proveru, pa je naše istraživanje teklo u dva pravca. S jedne strane, predstavili smo pregled kritičkih ocena samih pisaca i kritičara, odnosno recepciju ovog fenomena u međuratnom periodu (Ivan Pregelj, France Bevk, Miran Jarc, Juš Kozak, France Vodnik, France Koblar, Anton Slodnjak, Božo Vodušek, Josip Vidmar), kao i mišljenja savremenih teoretičara i istoričara (Lino Legiša, Franc Zadravec, France Bernik, Matjaž Kmecl, Boris Paternu, Helga Glušič, Marjan Dolgan, Gregor .Kocijan, Marija Mitrović, Lado Kralj). S druge strane, pokušali smo da kroz neposredan uvid u obimnu građu slovenačke literature i periodike (listovi i književni časopisi koji izlaze između 1914. i 1934/35. godine), pojedinačne zbirke, izabrana i sabrana dela pojedinih autora potvrdimo ili odbacimo tezu o zastupljenosti ekspresionističke proze u slovenačkoj književnosti. Pri tome, imali smo u vidu i specifične karakteristike istorijskog razvoja slovenačke kratke proze i njene strukturne modifikacije od druge polovine XIX veka do savremene književne scene.

Stoga, neophodno je sačiniti jednu uslovnu, indikativnu periodizaciju kratke proze s obzirom na udeo i pojedinačnu zastupljenost pojedinih žanrova. To svakako obuhvata promenu karakterističnih toposa, narativnih i stilskih modaliteta, kao i uzajamni odnos između pesama u prozi, crtice ili kratke priče u odnosu na pripovetku ili roman. Ekspresionistička proza može se sistematizovati u tri hronološka segmenta koje smo nazvali protoekspresionizam (1914-1919), formalno- 
eksperimentalni ekspresionizam (1920-1923), kao i zreli i pozni ekspresionizam (1924-1929/30). Nova stvarnost ili metafizički realizam u periodu od 1930 do 1935. godine nasledio je neke od važnih elemenata ekspresionističkog pokreta, pa ga u tom kontekstu i pominjemo.

Kao rezultat opsežnog induktivnog istraživanja, utvrdili smo da više od dve stotine tekstova u ovom periodu mogu biti imenovani kao ekspresionistički, jer ispunjavaju pojedine kriterijume koji su definisani modelom ekspresionističkog proznog teksta. To takođe znači da samo mali broj autora može biti označen terminom ekspresioniste bez ostatka, iako su skoro svi autori u pojedinim fazama svog književnog stvaranja pisali ekspresionističke tekstove, ili su to radili u kontinuitetu (npr. Jarc ili Pregelj). Zbog toga, metodološki je primerenije govoriti o pojedinačnim kratkim proznim vrstama i njihovoj zastupljenosti kod pojedinačnih pisaca, koji bi trebalo da budu predstavnici ovog tipa proze.

S obzirom na ovakav pristup problemu, ključno je proučavanje međuratne književne periodike, jer to omogućava direktan uvid u stvarnu proznu produkciju celokupnog razdoblja, klasifkaciju pojedinih vrsta i njihovih strukturnih karakteristika. Prozne zbirke slovenačkih ekspresionista uglavnom su objavljene sa velikim zakašnjenjem, često tek u naše vreme (Stanko Majcen, Juš Kozak, Miran Jarc, Slavko Grum, Srečko Kosovel), dok su neki tekstovi sačuvani samo u novinama, listovima ili časopisima (npr. Andre Čebokli, Štefanija Ravnikar-Podbevšek, Stane Melihar, Bogomir Magajna, Bratko Kreft, Edvard Kocbek). Najveći broj ekspresionističkih kratkih proznih tekstova objavljeni su u Domu in svetu i Ljubljanskom zvonu, Modroj ptici i Jutru, kao i avangardnim časopisima Antona Podbevšeka Rdeči pilot i Trije labodje. Kada je reč o štampanim zbirkama, u ovom periodu je objavljeno ukupno jedanaest zasebnih zbirki sledećih autora: Ivana Cankara (1917), Franca Bevka (1922, 1923), Antona Novačana (1923), Antona Podbevška (1925), Makse Šnuderla (1929), Ivana Dornika (1931), Ludvika Mrzela (1931), Rudolfa Kresala (1941) i Vladimira Bartola (1935). Tu se ubrajaju i dve knjige Izabranih dela Ivana Preglja iz 1928. i 1929. u kojima autor objavljuje svoje najvažnije ekspresionističke novele.

U prvom hronološkom odseku od 1914. do 1919. godine, pesma u prozi i crtica predstavljaju vodeće kratke prozne žanrove. Najznačajniji pisac ranog ekspresionizma je Ivan Cankar sa svojom poslednjom zbirkom kratke proze Slike iz snova (Podobe iz sanj, 1917), u kojoj još uvek preovlađuju simbolističko- 
impresionističke narativne i stilske tendencije. Međutim, neke kratke priče iz nje (npr. „Gospodin poručnik“, „Kesten osobite sorte“, „Velika misa“, „Maj“, „Jedina reč“", „Kraj“) pokazuju znatne inovacije, na tematskom, narativnom i stilskom nivou. Ovo je posebno primetno u Cankarevoj tematizaciji toposa smrti i apokaliptičkog iskustva rata, u promeni narativnog modusa od trećeg u prvo lice, ili u kolektivnu „mi formu“, kao i naglašavanje metatekstualnosti, fantastičnog, grotesknog i paraboličnog pripovedanja. Narator ujedno problematizuje dogmatično, hrišćanskokatoličko doživljavanje boga, što se iskazuje u skladu sa izmenjenim stavom i dualističkom prirodom ekspresionističkog proznog subjekta, koju je nasledio iz Ničeove koncepcije Hrista kao psihološke figure. Ona će biti važna komponenta Pregljevog pogleda na svet i principa oblikovanja junaka, kao i nekih saradnika časopisa katoličke orijentacije Dom in svet i Križ na gori.

Kod autora kao što su Ferdo Kozak, Ivan Rozman, Peter Popotnik, Marija Kmet ili Ivan Dornik može se uočiti heterogeni uticaj modernih stilova toga perioda: naturalizma, impresionizma, dekadencije, simbolizma, kao i individualna obrada pojedinih ekspresionističkih toposa (sukob između muškaraca i žene) u retoričnopatetičnom maniru. Motivi rata, dezerterstva i egzistencijalne patnje prisutni su u crticama Franca Bevka, Stanka Majcna, Narta Velikonje i Ivana Dornika.

Tokom faze formalno-eksperimentalnog ekspresionizma (1920-1923) uglavnom dominiraju avangardne tendencije poništavanja i otpora postojećem redu i konvencijama žanra, odnosno roda. Ova grupa umetnika i pisaca poznata kao „Novomeško proleće“ bila je okupljena oko Antona Podbevšeka i njegovog levičarskog časopisa Rdeči pilot i Trije labodje (Štefanija Ravnikar, Stane Melihar, Ciril Vidmar). Miran Jarc i Andre Čebokli objavljuju uglavnom u Domu in svetu, dok Jarc ima širok prostor za obkavljivanje svojh multižanrovskih dela, koji je ideološki neomeđen. Formalno-eksperimentalni model ekspresionističkog teksta ima izrazito antimimetičku prirodu. Ovde je reč o sintagmatskom povezivanju jezičkih krhotina i tekstualnih mikrocelina, što rezultuje fantastično-grotesknim diskursom. U tekstu dolazi do kolapsa sintaksičnih jedinica koje se raspadaju na pojedinačne reči, sintagme i izjave. Takav postupak potpuno drugačije utiče na na čitaoca i njegov prijem teksta, što je inače kod svih avangardista bio problem između očekivane i realne recepcije (Stojanović Pantović 1998: 24-25).

Kako su već uočili istraživači dela Antona Podbevšeka, ovaj autor je stvorio 
poseban oblik međužarovske strukture ili diskursa koji se istovremeno može nazvati i poetskim i proznim tekstom. U svojim pesmama u prozi „Himna o caru duginih zmija“ (DS 1920), „Čarobnjak iz pakla“ (DS 1921) i „Plesač u tamnici“ (TL 1922) udeo konstruktivnih, proznih celina je takav da tvori specifičan tip poetske ili lirske proze, odnosno pesme u prozi. Te činjenice je bio svestan Fren Petré (1978: 5356), ukazavši na neuobičajeno dug Podbevšekov stih koji se približava ritmičkoj prozi. Stoga on funkcioniše bez stiha kao dinamična, simultana proza, kao što su to primetili značajni međuratni kritičari (France Vodnik i France Stelé).

Efektan postupak montaže primenio je Podbevšek u tekstu „Himna o caru duginih zmija.“ On je u potpunosti formiran od proznih fragmenata, pri čemu je pesnik koristio razna vizuelno-grafička rešenja njegove segmentacije, s ciljem da kreira što sugestivniju jezičku realnost diskursa. Deskriptivna tehnika pamćenja, oživljavanja, sanjske igre, metamorfoze i vizije subjekta - gube svoju mimetičku funkciju i menjaju se u samostalni jezički entitet koji se realizuje kao signatura značenja. Podbevšek majstorski varira jedan motiv iz različitih uglova i perspektiva, gotovo kubistički. Takav primer može se naći u hiperboličkoj slici subjektovog „kosmičkog bola“: „Zmije su se besno zaletele u moje grudi, lizali su me vatreni jezici, krokodili jeli halapljivo, iz moje glave su izletale ptice, udarali gromovi i sevale munje, a ja večno napaćeni pesnik pevao sam kao nikada pre, i sa gašenjem komete shvatio sam da neću prestati sa svojim nebeskim pevanjem“ (DS 1920:105). Ima ovde nešto od ekstatične pesničke pozicije Gijoma Apolinera, futurističke fascinacije budućnošću, nadrealističke metaforike podsvesnog, ali i od autentičnog impulsa našeg Rastka Petrovića.

$\mathrm{U}$ tom periodu se takođe javljaju i značajne novele pojedinih autora, kao što su Juš Kozak, Miran Jarc i Ivan Pregelj. Dominacija kratke priče i novele karakteristični su u sledećoj fazi razvoja ekspresioniste proze od 1923. da 1929. godine. Ovo je period intenzivnog stvaranja Preglja, Gruma i Jarca, koje su pojedini savremeni književni istoričari (npr. Marjan Dolgan u svojoj studiji Tri ekspresionisticke slike sveta, 1996 ) proglasili ključnim slovenačkim prozaistima. Uz njih je svakako potrebno pomenuti i doprinose u kratkoj prozi Srečka Kosovela, kao i Grumove sjajne crtice. I ovde je reč o interakciji između različitih žanrova kratke proze fluidnih granica i konvencija, kako bi se omogućio što slobodniji jezički prostor. Od 1929. javlja se nova generacija proznih pisaca, kod kojih se mogu 
zapaziti egzistencijalističke tendencije (Ludvik Mrzel), ili aktualizacija simbolističke koncepcije sveta (Rudolf Kresal). Oba autora pišu subjektivizovane lirske tekstove sa meditativnom atmosferom i fragmentarizovanom fabulom, nagoveštavajući autore novog realizma.

U navedenom kontekstu, osim Bevka, Gruma, Jarca, Preglja, Majcna, Novačana i Magajne, posebnu pažnju treba obratiti na kratku prozu Srečka Kosovela (1904-1926), koja je izašla u okviru autorovih Sabranih dela koje je priredio Anton Ocvirk. Po čuvenom slovenačkom komparatisti i bliskom Kosovelovom prijatelju, pesnik je svoje crtice i pesme u prozi pisao u periodu od 1924. do 1926. godine (Ocvirk 1974, II: 667). U Kosovelovoj zaostavštini pronađeno je, naime, oko stotinu pesama u prozi i šezdeset crtica i kratkih priča. Ova činjenica potvrđuje stav da kratke prozne vrste, pogotovo pesma u prozi, za velikog avangardnog pesnika nisu bile tek marginalno polje književnog delovanja. Njegove pesme u prozi ukazuju na visok stepen povezanosti sa tematsko-motiviskim odlikama njegove poezije. Pre svega tu su motivi iz kraškog područja, ljubav prema majci i ženi, kao i naglašeno porodično osećanje, teme rastanka i nostalgije. Tome treba dodati i bitne ekspresionističke poetske topose: slutnju smrti i usamljenost, egzistencijalnu rezignaciju i nesigurnost, a s druge strane vitalistički i dinamičan odnos prema životu, kao i apokaliptičke vizije. Iako su najbrojnije impresionističko-simbolističke pesme u prozi i kratke priče, značajan udeo imaju i tekstovi napisani formalnom ekspresionističkom stilskom tehnikom, koja se očituje pre svega u sintaksički izlomljenoj rečenici, brzoj izmeni glagola i imeničkih sintagmi, montaži fantastičnih prizora, u eliptičnim formulama i diskurzivnim opisima, itd.

Kosovel je svoje pesme u prozi uglavnom oblikovao kao dramatičnu ispovest egzistencijalno podvojenog subjekta. Zato se pita: „Ko sam ja“, „Šta sam ja“, „Zašto živim“, kako prevladati očajničku prazninu koju lirski subjekt oseća u sebi i oko sebe. Kosovelova egzistencijalna motivika može se razvrstati u tri kruga pitanja: „Sumnjam, dakle, sumnja postoji“ („Pismo“), čovek kao večni putnik u potrazi za spoznajom života („Teški snovi“ „Zima“, „Kosmički život“), kao i iskustvo usamljenosti i anksioznosti („Kratka pisma“, „Noć kuca na prozor“, „Lice u samoći“). Takođe, u Kosovelovoj poeziji i prozi dominantan je topos smrti, a jednako su važne vizualizacija i simbolizacija boja, što upućuje na vezu s apstraktnim ekspresionizmom Vasilija Kandinskog i njegovom avangardnom slikarskom grupom 
grupa „Plavi jahač“. („Tri boje“, “Samotni oblak“ „Uskršnje“, „Plavi konji“ itd.). Posebno je zanimljiva pesma u prozi „Plavi konji“, koja je prozna verzija Kosovelove lirske pesme „Nihilomelanholija“, inače svojevrsna replika na sliku „plavih konja“ minhenskog ekspresionističkog slikara Franca Marka (Stojanović Pantović 2003: 164-165). Pesnik ovako završava tekst: „Neko je išao kroz predeo smrti, i zaustavio se ispred drveta. Plavi konji su prolazili pored njega. Čuo ih je, video nije. Na prozoru se neko pomerio. Sve je kao mrtvo. Plavi konji mrtvačkoga sna plivaju kroz maglu. Ni drveće više ne vidim jasno. Znam samo za dve boje. Crnu i sivu. Na prozoru plače čovek. Joj, nije umro“"(ZD II: 282). Sumorni predeo se u jednom trenutku preobražava u pejzaž smrti, kroz koji koračaju nevidljivi i nečujni plavi konji, fantomske slike iz snova, izaslanici Tanatosa. Tako se naglašavanjem crne i sive boje (smrt i praznina) utiče na stvaranje fantastično-mistične atmosfere teksta, što je karakteristično i za njegove crtice i i kratke priče koje su narativno razvijenije (npr. „Harmonični svet“, „50 grama ciankalija“, „Saputnik“, „Mistični talisman“).

Iz perioda metafizičkog realizma posebno je zanimljiva lirsko-asocijativna putopisna proza Edvarda Kocbeka Svetlosti severa (Luči na severu) koja je objavljena u Domu in svetu 1932, dve godine pre objavljivanja njegove prve pesničke zbirke Zemlja (1934). Ovde autor tematizuje ekspresionistički topos odnosa pojedinca prema društvu i njegovo otuđenje. Pored toga, Kocbek autoreflektuje svest o krizi jezika i identiteta stvari, ukazujući na gubitak veze između označitelja i označenog. Na ovaj način, Kocbek spontano nagoveštava neke pretpostavke postmoderne književnosti, a pre svega metatekstualnu komponentu teksta, koja se upravo razvija u doba procvata modernističke proze. Tako Kocbek sasvim u duhu sinestezije i svojevrsnog sumatraizma, slično Gotfridu Benu i Milošu Crnjanskom, piše: „Još sasvim malo se znak drži stvari koju označava. Nije više ime, zapravo je još samo označitelj, egoistično posezanje u rast i umiranje stvari. Ko se zaista zamisli nad čudesnom mešavinom koju nazivamo hleb? Ko se seća stvarne zemlje, kiše, zvezda i gline? Neki predmeti nisu sami prestali da postoje. Grče se u prizemnosti i čekaju dan koji će ih pozvati“" (DS 1932, br.3: 93).

Ako ovo razdoblje posmatramo u celini, primetićemo vidan raskorak između teorijskih, eksplicitnih ideja o modernizaciji kratkih proznih vrsta i konkretne spisateljske prakse, što je odlika i drugij južnoslovenskih književnosti, posebno srpske. Prvi prozni tip može se označiti kao „mesijanski ekspresionizam“ (Vietta, Kemper 
1979: 56-59) u kom je prisutan patetičan krik za oslobođenjem „Novog Čoveka“ i otpor prema civilizaciji. Ovaj apelativno-retorički obrazac pre svega se odnosi na pesme u prozi Juša Kozaka, Ivana Dornika, Mirana Jarca, Andreja Čeboklija, Rudolfa Kresala, Ivana Preglja. Drugi tip je označen kao „kritički ekspresionizam“ u kom autori svesno ili ne polemišu sa pretpostavkama moderne civilizacije, kulture, politike i idelogije. Upravo zato ove odlike znače ozbiljnu inovaciju i revolucionarnost ekspresionističke literature, i među te autore ubrajamo Bevka, Gruma, Jarca, Šnuderla, Mrzela, Kosovela, Preglja, Kozaka, kao i Kocbeka i Vladimira Bartola. Istovremeno, treba istaći da se fenomen slovenačke ekspresionističke proze prozi ne može izučavati nezavisno od postmodernističke književnosti. Njeno razumevanje i tumačenje bilo bi nezamislivo bez avangardnog iskustva slovenačkih ekspresionista, posebno zbog njihove prakse formalno-jezičkog i žanrovskog eksperimenta.

\section{LITERATURA}

Althaus, Thomas, Bunzel, Wolfgang Hgg. (2007). Kleine Prosa. Theorie und Geschichte eines Textfeldes im Literatursystem der Moderne. Tübingen: Niemeyer.

Andreotti, Mario (1990). Die Struktur der modernen Literatur. Frankfurt : Suhrkamp. UTB.

Anz, Thomas (2002). Literatur des Expressionismus. Stuttgart-Weimar: Metzler.

Anz, Thomas und Stark, Michael(1994). Die Modernitätdes Expressionismus. Stuttgart: Metzler.

Aust, Hugo (1990). Novelle. Stuttgart: Metzler.

Barthes, Rolland (1971). The Style and his Image. Literary Style, ed. by S. Chatman. London-New York. Oxford University Press: 3-10.

Bernik, France (1984). Ekspresionizem in slovenska pripovedna proza. Obdobje ekspresionizma v slovenskem jeziku, literaturi in kulturi. Ljubljana: Univerza v Ljubljani, 34-52.

Dierick, Augustinius P. (1987). German Expressionist Prose - Theory and Practise. Toronto: Toronto University Press.

Dolgan, Marjan (1996). Tri ekspresionistične podobe sveta. Ljubljana: 
Državna založba Slovenije.

Fähnders, Walter (2001). Expressionistische Prosa. Bielefeld: Aisthetis Verlag.

Jens, Inge (1997). Die expressionistische Novelle: Studien zu ihrer Entwicklung. Tübingen: Attempto-Verlag.

Kosovel, Srečko (1974). Zbrano delo, knj.II, ur. A. Ocvirk. Ljubljana: Državna založba Slovenije.

Kralj, Lado (1986). Ekspresionizem. Ljubljana: Državna založba Slovenije.

Krull, Wilchelm (1984). Prosa des Expressionismus. Stuttgart: Metzler.

Martini, Fritz (1983). Prosa des Expressionisus. Stuttgart: Reclam.

Marx, Leonie (1985). Die deutsche Kurzgeschichte. Stuttgart: Metzler.

Petré, Fran (1978). Zwei experimentelle Formen in slowenischen Expressionismus. Expressionismus in europäischen Zwischenfeld. Hrsg. von Z. Konstantinovic. Innsbruck: Institut für Sprachwissenschaft der Universität Innsbruck,51-62.

Sokel, Walter H. (1969). Prosa des Expressionismus. Expressionismus als Literatur. Hrsg. von W. Rothe. Bern-München: Francke

Walter H. Sokel (1970). Der literarische Expressionimus. München: A. Langen.

Stanzel, Franz K. (1989). Theorie des Erzählens. Frankfurt: Suhrkamp. UTB.

Стојановић Пантовић, Бојана (1995). Кратка експресионистичка проза у јужнословенским књижевностима. Линија додира (студије и огледи). Горњи Милановац: Дечје новине, 187-202.

Стојановић Пантовић, Бојана (1998). Српски експресионизам. Нови Сад: Матица српска.

Stojanović Pantović, Bojana (2003). Morfologija ekspresionističke proze. Beograd: Artist.

Stojanović Pantović, Bojana (2010). Aspekti identiteta u poetici ekspresionizma. Susretkultura, zbornik radova sa V međunarodnog interdisciplinarnog simpozijuma, knj.2, ur. Lj. Subotić i I. Živančević-Sekeruš. Novi Sad: Univerzitet u Novom Sadu-Filozofski fakultet, 955-960.

Vietta, Silvio, Kemper, Georg (1979). Expresionismus: München. UTB.

Вучковић, Радован (2000). Српска авангардна проза. Београд: 


\section{Откровење.}

Bojana Stojanović Pantović

\section{SHORT EXPRESSIONIST GENRES AS A MODERNISTIC SIGN IN SLOVENIAN LITERATURE}

\section{Summary}

This paper raises the question of the existence of Expressionist prose as a significant segment of the Slovenian literary movement between the two world wars. It points out at a fundamental ambivalence about its relationship to the typological-aesthetic concepts of modernism and avant-garde. The problem lies in the fact that Slovenian literary historians and critics between 1920-1930, as well as the contemporary ones (with some exceptions), were detained and refused to accept innovative position of this phenomenon. Therefore, expressionism was often understood simply as a radicalization of the poetic elements of Slovenian impressionism (1895-1916), and this view is particularly evident in the assessment of Lado Kralj (Expressionism, 1986).

Due to the uncertain and indeterminate previous definitions of the expressionist prose, whose research in German literary criticism, especially from the nineties to the present, yielded significant results (W. Sokel, S. Vietta, G. Kemper, B. Scheffer, W. Krull, A. P Dierick, I. Jens, T. Anz, M. Stark, W. Fähnders), there is a need for a new, more flexible pattern of the expressionist prose text. For the identification of this model the following aspects were taken into account: Poetical and conceptual aspects, Expressionist topoi, Morphologic and narrative aspects, Stylistic and linguistic aspects, following by Semantic Implications.

Textual base of Slovenian short expressionist fiction includes 11 collections, published between the two world wars, and more than 200 prose pieces in the leading Slovenian magazines and newspapers. Works of the individual authors were recently acclaimed in publishing monographs, mainly posthumously (S. Majcen, M. Jarc, J. Kozak, S. Kosovel, S. Grum, E. Kocbek).

In the interpretation of a characteristic prose samples (Podbevšek, Kosovel, Grum, Pregelj, Kocbek) one can notice the type of discourse and style-rhetorical moves that shape the Slovenian short fiction (prose poem, sketch, short story and novella). Similar to German expressionism, in the Slovenian literary movement the short prose genres play fundamental role in the process of a structural modernisation. 